\title{
Animating African History: Digital and Visual Trends
}

Paula Callus

\section{Summary}

Contrary to popular belief, the animated moving image on the African continent has long and diverse histories across many countries. Although it shares both the technology and some of the formal aspects of cinema, its historical development followed a different trajectory to that of indexical film, both in Europe and in Africa. This may be because of animation's ability to draw upon a range of artistic practice, which has meant that it can take many guises; at times appearing like a cartoon, other times like puppets or sculptures that come to life, a metamorphic drawing or painting, and even a photographic montage. In addition, whilst animation tends to be associated with content specifically intended for a children's audience, it has in fact been an effective vehicle to conceal socio-political critique that would otherwise be considered problematic. Different animators in Africa have used animation to this end, presenting subversive and social-realist content within the unrealistic depictions of fantastical stories, the parodic, comedic or allegorical, or culturally located visual metaphors. African animators have also used animation to safeguard and give permanence to the stories, myths and legends they grew up with. These legends have occasionally also informed animated super-heroes in games like the Kenyan mobile phone application Africa's Legends, or the cast of an Afro-futurist setting such as Nigerian 'Afro-anime' production Red Origins. ${ }^{1}$ With the onset of digital technology the landscape of animation in Africa has seen a mushrooming of activity from expert and non-expert prod-users. ${ }^{2}$ Their work circulates in formal and informal settings, 
whether visible at a festival, on television and mainstream media, in online socialnetworking spaces or on video streaming sites such as YouTube or Vimeo. The prolific characteristic of animation made for digital spaces has resulted in a paradoxical simultaneous visibility and invisibility. Networks of African artists have benefitted from the visibility and distribution that the Internet and smart phone technologies offer; for example Kenyan multi-media artists Just a Band were quoted as saying that they were discovered online before they were discovered in Nairobi. However the ephemeral and transient quality of these digital spaces can also be problematic from the archivist's perspective as digital traces move and change. For this reason it is increasingly important to capture the traces that African artists leave in this dynamic space as they reflect the zeitgeist.

Key Words: African Animation, Animation Studies, African Film, New Media

\section{Animation Studies: Dominant Narratives from the Periphery}

The animated moving image is conventionally thought of sitting within the chronicles and histories of European and American cinema. Consequently animation in Africa has had very little attention at the same time as these narratives were emerging. In addition, the hegemonic accounts of key figures such as Disney or Warner Brothers have tended to frame the discussion of animation as a form associated with the genre of children's content and unworthy of serious academic attention. This has positioned animation somewhat on the periphery of academic discourse of the histories of the moving image as animation studies scholars such as Gehman and Reinke (2005) and Furniss (2017) have noted. ${ }^{3}$ With the exception of Dorfmann and Mattelard's How to 
Read Donald duck: Imperialist Ideology in the Disney Comic (1975), a critical analysis of the cultural impact of mainstream animation was rare.

It wasn't until 1989 that the Society of Animation Studies (S.A.S.) hosted its first academic conference on animation in Los Angeles. A few years later, in 1992, the Association des Realisateurs des Films d'Animation d'Afrique (A.R.F.A.A.) [Association for Producers of African Animation] was formed during an animation training course hosted by the Bordeaux International School, with Moustapha Alassane from Niger as President ${ }^{4}$. However, when five years later the founder of S.A.S. Jayne Pilling published A Reader in Animation Studies (1997), the collection of the papers from conferences between 1989 and 1997 did not include any mention of animation from Africa. Despite this, the book did mark the start of a more active and analytical engagement with the animated form. It ushered in critical analysis that saw animation as problematically in the service of culturally imperialistic tropes within mainstream content ${ }^{5}$, or in contrast as a political tool of resistance ${ }^{6}$. Later, with the onset of digital technology animation studies would experience a renaissance. Animation had become increasingly more important and present in filmmaking practice $^{7}$ with the onset of CGI (Computer Generated Imagery) and the growing popularity of interactive content, gaming and subsequently smart phone apps have brought to light convergences across different fields (computing, filmmaking, art practice, new media). ${ }^{8}$ During this time discussions and formal interest in histories and practices of animation from the African continent have continued to be sporadic and European and American content tended to dominate the field of animation studies. 
Conversely, histories of the moving image from the African continent have been documented and framed by the largely varying Franco or Anglophone colonial and post-colonial contexts with a focus upon cinema in the conventional photographic sense $^{9}$. These narratives very rarely make reference to other types of moving image such as the animated moving image. This may be in part due to the fact that animation uniquely draws upon a range of different artistic practices (whether drawing, painting, sculpture, choreography, theatre) and also because it did not experience the same vigour of post-colonial filmmaking in the 1960s. Similarly mention of the animated moving image in literature on African arts, is limited to a few well-known artists, such as William Kentridge (South Africa), Wangeci Mutu, Jackie Karuti, Phoebe Boswell, Peterson Kamwathi (Kenya), Ezra Wube (Ethiopia) and Massinissa Selmani (Algeria). ${ }^{10}$

This impression of scarcity is not an accurate reflection of the range of 'art-making' practices in animation across different spaces in Africa: the cinematic, theatrical, mediascapes, galleries or virtual online spaces. In 1996, commenting upon this perception, the film Cand animation scholar Bruno Edera remarked that 'most experienced observers believed the total number of African animated films to be no more than thirty', even though his own research at the time demonstrated otherwise. ${ }^{11}$ In fact artists and filmmakers across the continent were making animation; from as early as 1916 in South Africa with Harold Shaw's The Artist's Dream (1916), in Egypt in the 1930s the Frenkel brother's made Mish Mish Efendi (1930), in the DRC the stop-motion Les Palabres de Mboloko (1955) was a popular favourite, and later in Niger Moustapha Alassane's famous Bon Voyage Sim (1966) would become widely regarded as the first post-colonial Sub-Saharan animation. Between 2006 and 2017, 
the modes of animation (and access to any related material in the form of still or moving images, information and communication across networks of artists) in the Sub-Saharan region changed dramatically. The infrastructural changes to the technological landscape, including the penetration and availability of the mobile phones, the Internet and related computer technologies has seen a change in the exposure and distribution of animation across a range of African countries and a flourishing of content in new digital spaces.

\section{Literature on African Animation}

As mentioned earlier, monographs that specifically address practices of animation from the different regions or countries in Africa were scarce and irregular but not inexistent. Bruno Edera offered the first retrospective of African animation at Annecy's International Film Festival in 1993. At the time, Edera had said, "To my knowledge, there exists no piece of literature that is specifically dedicated to the African animated film itself." ${ }^{12}$ His contribution brought together a tentative list of key animators from the continent and offered limited information that resulted from personal communications, interviews and a handful of published articles and animation festival publications. The publication listed a filmography of 230 films and 117 named artists and filmmakers from across the continent. One of the difficulties Edera faced at the time, and that some scholars continue to face, was the differentiation between animations about or inspired by Africa versus animation that is made by African artists and filmmakers. The separation that Edera called for was an important political point as it alluded to the appropriation of stories and artistic tropes from different African countries that some European animations had been responsible 
for, and that muddied the waters when trying to define 'so-called' African animation. In addition it instigated a questioning of the notion of 'authenticity' and the associated aesthetic expectations that Western academics and specialists had of African animation. This problem extends into the discourse on the animations of mobile African artists who tend to operate in a transnational context (moving across and between different geographical spaces) producing work that may present 'intertextual qualities $^{, 13}$. For the scholar, these tend to be harder to locate as they draw upon and represent the interactions that the artist experiences with different visual cultures. They also highlight the complexities of identity that can arise in an age of global mobility.

African Cartoon (2003) by Maria Silvia Bazzoli should be considered as one of the key contributions to a narrative of animation from the continent that gives a sense of the breadth of activity. With references to animation in Senegal, South Africa, Egypt, Tunisia, Niger, the DRC, and Zimbabwe (as opposed to merely a select few), Bazzoli's book highlights the dearth of knowledge in this field. It offers an edited compilation of interviews and articles by filmmakers and scholars reflecting and recollecting personal histories of animation from a range of countries in Africa. The book is split in two parts. The first section draws upon scholarly knowledge to offer a more academic discussion that frames so-called 'African' animation and its connections to other traditions of artistic practice, historical and contextual accounts of its development in different countries, and foci on named artists, such as South African artist William Kentridge or the Frenkel brothers in Eygpt. ${ }^{14}$ The second part of the book is framed as a collection of "Testimonials", and includes conversations and interviews with artists such as Cilia Sawadogo (Burkina Faso), Mohamed Aram 
(Algeria), Moustapha Alassane (Niger), Jean Michel Kibushi Ndjate Wooto (DRC), William Kentridge (South Africa) and Pierre Sauvalle (Cameroon). The testimonial account plays an important part in illustrating a lack of official documentation of animation history from this region, and the need to draw upon personal memories to portray these various histories. In this regard, it parallels African historical studies in general, which have drawn on a rich oral tradition across the continent.

The most recent publication on Sub-Saharan African animation focused upon animation from Central Africa is Guido Convents' book Images and/Animation: Le Cinema d'animation en Afrique Centrale (2014). This book offers an introduction to animation from the Democratic Republic of Congo (DRC), Rwanda and Burundi. In places the book offers a fragmentary narrative and relies upon capturing glimpses of moments in the history and development of animation from this region. It is the specific discussion of animation from the DRC that is more comprehensive and includes specific details on the colonial and postcolonial contexts within which animation was made and exhibited. It includes references to artistic practices such as cartooning and poputar painting, the exhibition and consumption of animation between Belgium and the DRC and its political use during the colonial period, and the developments of animation in a post-independence context, with a special focus upon the filmmaker and animator Jean Michel Kibushi.

More recently scholarly literature within animation studies, such as Bendazzi's Animation a World History (2015) has offered a listing of some key African animators and animations that tend to be known of in an international context. His book includes a list of 22 countries from Africa, but unlike other sections of the book 
this is one of the briefer sections and only offers more detail for entries for South Africa and Zimbabwe. Therefore, as Bendazzi's references to African animation are within a compendium of world animation they tend to lack a detailed analysis of the context, practices and artistic trajectories that may have informed these artists.

This is not the case in the publication Animation in the Middle East: Practice and Aesthetics from Baghdad to Casablanca (2017). This book is an edited collection of specialist articles that introduce the reader to animated films from the Middle East and North Africa. As the editor Van de Peer outlines in the introduction, this volume was intended to 'contribute to and influence the process of dissident canon formation through creating new audiences... scholarly or otherwise'. ${ }^{15}$ The book includes narratives about animation from Saudi Arabia, Iran, Iraq, and Turkey and other chapters that deal specifically with African animation. These include; a history of animation in Egypt, ${ }^{16}$ political animation in Libya amidst the Arab revolutions, ${ }^{17}$ the development of Tunisian animation from within a nation building to authoritarian political context, ${ }^{18}$ and new modes of animation in Morocco in an age of digital technology. ${ }^{19}$ The book is underpinned by an academic approach that actively engages with the relationship between artistic practices and the socio-economic and political conditions of these differing contexts.

\section{African Animation: Regional Impressions}

Framing a discussion of African animation is necessarily shaped by the different socio-economic and political environments of the countries in this continent. This has resulted in discontinuous and disparate histories of animation, which are reflected in 
the overview presented here. Contrasting histories of animation are visible across the continent; in South Africa for example, one would describe the growth of an ecology that is akin to a small industry of animation made for local and trans-national audiences with an infrastructure to support growth; in comparison for a long time the DRC had less than a handful of auteurs mobilizing the making and viewing of local animation since 1991 even though stop-motion animation was made in 1955 by Belgian missionaries. Therefore the section that follows will be organised by regional geographies but will not always include a full or detailed picture of animation from all countries in each region. It is intended to offer an impression of some of the trajectories of animation on the continent.

\section{SOUTHERN REGION - South Africa}

Animation from South Africa is considered to be the most prolific and visible in a Pan-African and transnational context. South African animation dates back to 1916 with The Artist's Dream by American Harold Shaw. ${ }^{20}$ In the 1920 s, the production of five animated shorts were made by the African Film Productions of I.W. Schlesinger. Then in the $1940 \mathrm{~s}$, animations moved into more commercial projects with the likes of Killarney Film Studio's making animated title screens for films, and Alpha Film Studio (1940-1967) making adverts. ${ }^{21}$ The demand for animation in the commercial market meant that by the 1970 s, animation was most successful in the advertising industry. Consequently, animation shifted from cinema to television, and between 1975 and 1988, the South African Broadcasting Corporation (SABC) set up an animation unit to create animated shorts with a white nationalist or patriotic agenda, 
and that also included advertisements. Animators Butch Stoltz and Gerard Smith headed the $\mathrm{Unit}^{22}$.

South Africa has uniquely benefitted from a relatively more robust infrastructure that could explain the earlier introduction and investment in technology, film, media and the arts, alongside the educational establishments required to support this growth. However it is worth noting that it was only with the end of the apartheid that black South Africans gained access to the formal institutions of art education, and that from '1948 to 1980 black and white audiences were treated differently. They were separated. Each with their own set of rules and operations, films and theatres. ${ }^{23}$

Of all the countries in Africa, the story of the development of animation in South Africa has the closest resonance with the industrial developments of animation in Europe or the US. One is able to speak of animation studios that have serviced the television and advertising industries, as opposed to a group of auteurs and independent artists. ${ }^{24}$ Notably, for example, the animation studio Triggerfish has grown from a small group of animators in 1996 producing animated 2D and stopmotion shorts for Takalani Sesame (2000-2001) to a company large enough to produce $3 \mathrm{D}$ feature-length computer animations such as Adventures in Zambezia (2013), Khumba (2015) and operate in a transnational context by working on commissioned short productions for BBC1 such as Stickman (2016) and Revolting Rhymes (2017). ${ }^{25}$

With that said, of notable mention is the animated documentary Beyond Freedom (2006) directed by Jacquie Trowell (one of the founders of Triggerfish). This film is a 
collage of reflections on freedom and race through the testimonies of different South Africans who lived through apartheid. Aimed at an adult audience, it uses a range of aesthetic devices as a vehicle to reflexively explore this history concluding with a nationalistic optimism on the future of South African society.

Within the arts, the individual that is most famously known for a critical engagement with the lived trauma of apartheid is the prominent artist William Kentridge (b.1955). Since 1989, Kentridge has made a series of animated drawings for exhibition in galleries. His 9 Drawings for Projection consist of charcoal drawings that metamorphose between states, as small changes are made to the same image in a process of drawing, erasing, and re-drawing. Through this work Kentridge explores the experience of apartheid and investigates memory (biographical) through the characters of Felix and Soho. Kentridge's work provides an exceptional example of African animation that garnered significant attention within international academic scholarly discourse and across the fields of animation, film, and fine art. ${ }^{26}$

\section{CENTRAL REGION - DRC}

In contrast to the economic successes of South African animation, from the 1990's animation in the DRC was championed by a lone auteur carving out a legacy of stories inspired by a social realist intention, critiquing systems of power (whether in the form of the military, the church or government) and offering permanence to his childhood stories. Jean Michel Kibushi Ndjate Wooto (b.1957) is a pioneer and advocate for the promotion and development of the arts and culture of his country. He 
has worked tirelessly not only to make his own animations but also to teach other artists how to animate, and to disseminate animations by other African filmmakers.

Critically Kibushi has taken on the mantle of a cultural proponent for the DRC and become a curator and historian for animation from the region. The knowledge that academics such as Bazzoli (2003), Convents (2014) and Callus (2010) have of early colonial animation in part stems from Kibushi's own retrieval and restoration of six of the seven stop-motion animations from the series Les Palabres de Mboloko (19511956). His knowledge of and communication with the Belgian animator Roger Jamar responsible for the making of the widely popular films culminated in the 21 minute documentary film that Kibushi made Roger Jamar and the Palavers of Mboloko (2015) that features interviews with the animator himself and testimonies from Congolese who recall the impact these films had in their youth.

Insert Figure1: Photo of Roger Jamar working on the set of Les Palabres de Mboloko Photo Courtesy of Jean Michel Kibushi

In 1951, Jamar was commissioned by a Belgian missionary Fr. Alexander Vandenheuvel, to make Les Palabres de Mboloko, as a didactic film intended for local audiences. Jamar's films were made using stop-motion techniques with rudimentary maquettes (dolls) from foam and latex with miniature sets and environments that were made out of pieces of wood, paper, real leaves and flowers. The stories featured a young antelope Mboloko who triumphs and outsmarts adversaries such as the crocodile and leopard. Significantly, the Mboloko tales were 
censored in 1965 by General Mobutu Sese Seko for their depiction of the leopard as a foolish rather than noble and powerful animal. ${ }^{27}$

Between the 1950s and the 1980s there is little information about animation in the DRC, and it was only in 1991 that a narrative of animation from the DRC resumes with Kibushi's first animated film. Kibushi's background is in drama and cinematography with an education from Kinshasa's National Institute of the Arts (INA) between 1985 and 1989. Following an animation workshop at the WallonieBruxelles Centre, Kibushi went on to co-produce with Atelier Graphiou, his first cutout animated short Le Crapaud Chez ses Beaux Parents (1991). For this reason, Kibushi is described as the first animation artist from the DRC in a post-colonial context. He then followed this film with his documentary animation Kinshasa Septembre Noir (1992), a collaboration with children from Kinshasa, during the military coup and looting of Kinshasa on the 23rd September 1991. In 1999, he made the social realist cutout animation Muana Mboka (1999), that follows a little street boy's misfortunes as he is rewarded for helping a minister and then harassed by corrupt characters representing the church, the military and criminals for the money. In 2004, Kibushi completed his longest and most technically accomplished film, a 29minute stop-motion film Prince Loseno (2004), which was awarded the special Prix COE at FESPACO in 2005. This film made use of latex puppets with professionally made armatures and complex sets, and tells the story of a king of the Confraternity of the Leopards who is goes to great lengths to have an heir.

In addition to producing his own work, Kibushi was able to secure funding to run projects such as Afriqu'Anim'Action (2012 - 2013). The project ran as a series of 
training workshops with artists from the DRC and Burundi and resulted in the production of eight animated shorts.

\section{WESTERN REGION - Niger, Ghana, Nigeria, Burkina Faso}

Animation from the West African region is characterized by the narratives of iconic figures such as Moustapha Alassane from Niger, key educational institutions such as NAFTI in Ghana, and trail-blazing entrepreneurs such as Adamu Waziri and Ebele Okoye from Nigeria, and Serge Pitropia from Burkina Faso, to name a few. The inevitable connection between local broadcasting, advertising and animation production is a theme that runs throughout most histories of animation in a global context and can also be seen here, where most of the earlier animations tended to have a didactic function or were used for advertising purpose. In contrast, with more recent independent animations it is possible to see content that is driven by the individual artists' own interests, such as Ghanaian Comfort Arthur's socially engaged work, or the Nigerian animator Ebele Okoye's culturally informed stories.

Niger

Moustapha Alassane, from Niger, is hailed as the father of Sub-Saharan animation. His career in this field began as a technician and mechanic, whereby he played with making his own magic lantern in the 1950s and later going as far as making his own camera. However it was through his meeting with the filmmaker Jean Rouch who was in Niamey at the time, that Alassane consolidated his love for filmmaking, learning the filmic techniques off Rouch. His early animations include Le piguier (1962), and La pileuse de mil (1962), followed by and Le Mort de Ganji (1965). In 1965, he 
travelled to Canada to study and work with pioneering animator Norman McLaren of the National Canada Film Board. Upon his return in 1965 he continued making more films and animations. His first animated film was made in 1965, Le Mort du Gandji, a drawn animation with anthropomorphized animals featuring a toad cast as a monarch. One of Alassane's more popular animations was the short film, Bon Voyage Sim (1966). This film is a drawn satirical animation on the pomp and grandeur of new African leaders of the time, and is cited as the first example of Sub-Saharan animation. ${ }^{28}$ Samba le grand (1977) and Kokoa (1985) on the other hand were both made using stop-motion techniques with puppets. Alassane's work in the field of African cinema also ensured that his name circulated in the related film literature, which was more prolific than that of literature on animation ${ }^{29}$. In 2007 , he was made a Knight of the Legion of Honour at the Cannes Film Festival for his contribution to African film and animation*. With Moustapha Alassane's death in 2015, the visibility of animation from Niger had diminished. In the most part, narratives about animation from Niger tend to refer to the doyen of Sub-Saharan African animation and little is currently known of contemporary artists from this country who are making animation. Insert Figure 2: Moustapha Alassane with one of his stop-motion frog puppets Photo Courtesy of Sylvie Bringas

\section{Ghana}

In Ghana, animation tends to be spoken of in connection with the setting up of the Ghana Broadcasting Corporation in 1965 and the Ghana Film Industry Corporation in 197, and yet neither produced an entirely animated film. Early animation of the time mainly served as animated graphics for title sequences, or animated inserts to educational and documentary films. ${ }^{31}$ The introduction of animation to a more 
prominent role can be attributed to NAFTI, the National Film and Television Institute, founded in 1978 (which became a regional institute in 1985). It catered to a larger catchment extending to countries outside of Ghana and south of the Sahara. ${ }^{32}$ NAFTI was the first educational institute to provide training that had a focus on animation. The type of animations being made in 1978 by NAFTI were more educational in purpose, commissioned by the ministry of education and generally very short in duration. These included for example Road Safety Campaign (1'20'), 'National Mobilisation and National Buidling' (50'). ${ }^{33}$ NAFTI is also the only institution that has the status to award a diploma in the study of animation and film that could feed into a Bachelors of Fine Art in affiliation with the University of Ghana.

Included in this trajectory of early animation in Ghana is the contribution and support of the Friedrich Ebert Foundation in contributing to educational programming on local television. The foundation's office in Ghana was setup in Accra in 1969 with a view to promote democratic processes. Unfortunately there remains no evidence of these early animations due to a fire that broke out in the audio-visual archive at the Ghana Broadcasting Corporation in 1993 that destroyed them.

Edward Aberese was one of the first animators to work with the Friedrich Ebert Foundation on developing animation for educational broadcasts. Aberese was then a young graduate from the Kwame Nkrumah University of Science and Technology in Kumasi, which is houses one of the country's best art schools. He was selected alongside others to form a core group of animators who would be trained under the auspices of German expert animators, who were working with the science educational unit at the time $\mathrm{e}^{34}$. They tended to produce mainly inserts for science programs such as 
Carbon Cycle, Power, Timber, Xylophone for Dancing, Backyard Industry, Cocoa, and others. $^{35}$

In 2007 Samuel Quartey, animator and lecturer at NAFTI, started the organization Animation Africa, with a view to promote animation, through screenings but also by encouraging the setup of local studios and providing workshops in schools. Animation Africa was also responsible for the setting up of ANIMAFRIK animation festival that began in 2008 and has ran subsequently every year since, in Accra, Ghana. The festival promotes animated films from the Sub-Saharan African and Caribbean regions and the diaspora ${ }^{36}$. During this festival in 2009, ASIFA (Association Internationale du Film d'Animation) awarded Moustapha Alassane with a prestigious prize for achievement and contribution to world animation.

By 2016, the landscape in Ghana had changed significantly. A generation of animators had acquired knowledge of computer animation (2D or 3D) through online social networking interest groups and uploaded and self-promoted their work on video streaming sites such as YouTube. Of notable mention are; the animator Cycil Jones Abban, and his studio Parables Animation Studio produced short animations that were inspired by Ghanaian stories such as Anansi Tales (2015-2016) and Storytime in Akwaaba that is screened on local television; Francis Yushau Brown and his animation Agorkoli (2015), that was made during his studies at NAFTI, and that depicts the migration of the Ewe group away from a tyrant king in Eastern Ghana ${ }^{37}$. In addition, one should consider Comfort Arthur a Ghanaian artist who has lived in the UK, and completed her studies in animation at the Royal College of Arts, London. She has made various animations from humourous to more serious content: these 
include the film The Peculiar Life of a Spider (2015), also inspired by the tales of Ananse, Imagine (2016), a short poetry animation about the Chibok girls that were kidnapped in Nigeria in 2014, the award winning Black Barbie (2016) and Untitled (2017), an animation about 13 stories of sexual harassment.

\section{Nigeria}

The discussion of animation in Nigeria takes place in the context of discrete divisions of the country; notably the North and the South, each of which presents a different landscape and approach to animation. In the Southern part of the country, in Lagos, it was possible to find a strong movement in the development of local graphic novels and cartoons (which have a long standing historical trajectory in relation to the newspaper industry). ${ }^{38}$ These tended to link well to subsequent development into animation.

The illustrator and animator Kenneth Shofela Coker, for example produces work in the graphic novel format, such as the crowd-funded The Outcasts of Jupiter, makes animations such as Oni Ise Owo (2008) and Iwa (2009) that unite Afro-futurist tropes with Yoruba mythologies, and elements that straddle both graphic novel and animation such as the living tableaus depicted in the Swaziland documentary Liyana (2017) by Aaron and Amanda Kopp.

Another key figure in the discourse of Nigerian animation is the artist Ebele Okoye, who works between Berlin and Lagos. Her 28-minute The Legacy of the Rubies (2015) won the Africa Movie Academy Awards (AMAA), the Africa International Film Festival (AFRIFF) and the Silicon Valley African Festival (SVAFF). Okoye has also been active in supporting the emergent animation community in Nigeria by 
running various training workshops, such as the Shrinkfish Media Lab smedLAB, founding The Animation Club Africa and being a mentor at the Zanzibar International Film Festival ZIFF (2016)

Finally, from the northern city of Abuja, Adamu Waziri runs a small animation company responsible for the Bino and Fino series (2007-). Waziri left a successful career as an animator in London, to pursue his ambition to create children's content that resonated with an African audience. With this in mind, he designed a 2-D digital cutout animation that is the Nigerian equivalent of Charlie and Lola (2005-2008).

Insert Image 3: Photo of EVLC studio in Nigeria that produces Bino and Fino Photo Courtesy of Adamu Waziri Insert Image 4: Photo of Bino and Fino in production editing stage. Photo Courtesy of Adamu Waziri

\section{EASTERN REGION - Kenya, Ethiopia}

Unlike most West African narratives of filmmaking in a post-colonial context, Kenya has struggled to foster and develop local film production and inevitably there are no testimonies of animation being made in the immediate post-independence years of the 1960s. In Kenya different accounts from local animators ${ }^{39}$ indicate that animation appeared as a practiced form as late as 1990 with the introduction of the first animation school, Mank \& Tank, set up by Kenyan John Githongo and Martin Khamala in Nairobi. In 2009 there were two other main colleges or training institutes based in Nairobi with a focus on computer animation. These were Shang Tao Media College, a private school endorsed by the government with state of the art technical 
facilities and studios, and The Institute of Technology, offering a diploma in animation and affiliated with Truemax Academy, Denmark. In the most part these educational establishments were set up to provide a service to the advertising and film industry, rather than seeing animation as an art form in its own right. In response to this, and to address a lack of local content in children's programming, UNESCO launched its Africa Animated projects than ran between 2004-2006. These projects were developed in Nairobi by educational and professional consultants from across the African continent and Europe and America. The project consisted of a 5 -week residency program for mostly East African artists, illustrators, and cartoonists, to be trained in animation and to produce animated shorts intended for regional broadcast. Many of the Kenyan artists that were trained on this project, subsequently went on to work for Tiger Aspect Productions' satellite studio based in Kenya to work on the award-winning Tinga Tinga Tales (2010) animated series commissioned by the BBC.

Insert Image 5: Serge Pitropia on sêt during the UNESCO Africa Animated Project Photo Courtesy of Paula Callus

In 2009, the Kenyan Film Commission's Kalasha Film and Television Awards was set up and has played its part in increasing an awareness of the presence of animation with special awards in 2011 going to Kwame Nyongo for his film, The Legend of Ngong Hills. In 2012, Andrew Kaggia won the Best Animation award for his film Wageuzi: Battle 2012 (2011), a computer-generated 3D animated film of a race between politicians as transformer cars, with overt references to the Transformers (2007, 2009, 2011). Kaggia and other multi-media artists at the time were active in 
creating animated content that was socially engaged and related to politics and the elections.

From 2011, the range of animated work that emerged from Kenya also grew in its scope and expression, moving beyond mainstream media formats such as adverts and children's programming to more provocative engagements with social and political issues through experimental and aesthetically diverse imagery. A few notable Kenyan artists are Mangeci Wutu, Ng'endo Mukii, Phoebe Boswell, Jim Chuchuand Peterson Kamwathi who have all been making work that draws upon animation or animated techniques, whilst not necessarily calling it so. This work can appear as projected drawings, manipulated photographic images, narrative and non-narrative pieces that address a range of personal interests alongside socio-political concerns such as migration, Afro-futurism, mythologies, skin bleaching and histories of colonialism. With the exception of Phoebe Boswell, who is a Kenyan residing in the UK, the other artists tend to make from Kenya whilst being cosmopolitan and regularly travelling, working or participating in residencies across Africa, Europe and the US. Their work tends to circulate within the gallery context, or in the cases of $\mathrm{Ng}$ 'endo Mukii and Jim Chuchu have straddled both the cinematic and gallery space.

\section{Ethiopia}

There is little available information about the existence of animation in Ethiopia and its circulation. Consequentially UNESCO's sponsorship of the first children's educational television show Tsehai Loves Learning (2005-) made by Bruktawit Tigabu is a rare example of the dissemination of animation with local content designed for a local audience. Tsehai Loves Learning is a children's television series 
that combines a hybrid of animation, puppetry and digital video as a colorful collage of adventures of Tsehai the giraffe in Amharic aimed to teach young children about environment, health, numeracy and literacy relevant to their own contexts. In 2008, the team won the award at the Prix Jeunesse International Children's Television Festival in Munich, Germany. Brukawit Tigabu has been driven by the ambition to create local content for children, and under the auspices of her production company, The WhizzKids, in 2016 she released a 2D animated series called The Tibeb Girls (2016). The animation is based on three adolescent young heroines that rescue and help other girls who face challenges. It is educational in its intention; it tackles subjects such as menstruation and child marriage and aims to positively promote young empowered women. In addition the animation operates in a trans-media context, where it is possible to read about their adyentures in printed comics, and listen to their adventures on the radio. Another addition to the animated children's content made in Ethiopia for an Ethiopian audience includes the series Abeba and Abebe (2011), produced through a collaboration of an Ethiopian media company Tamesol Communications, and a UK based BigFatStudio. The series was sponsored by the UNDP (United Nations Development Program) and was aired on national TV in Amharic, Tígrinya and Oromifaa.

The Ethiopian artist, Ezra Wube, migrated to the US as a young adult, and has been making animated paintings that engage with his experience of migration, identity and memories of home. He received his BFA in painting from Massachusetts College of Art, Boston, and an MFA from Hunter College, New York, $\mathrm{NY}^{40}$. Wube's range of work from 2003 to 2017 frequently returns to the tensions of being between different locales as visible in his own time-based paintings and installations that depict 
haunting images of nomadic Ethiopians in dislocated environments ${ }^{41}$. This thematic concern is echoed in other African mobile artists who may be travelling and living between Europe or the US and also Africa. Since 2015, he is also responsible for organizing the Addis Video Art Festival, that seeks to promote local and international video art.

\section{NORTHERN REGION - Egypt, Algeria, Tunisia, Morocco, Libya}

The earliest examples of North African animation can be found in Egypt that has a long history of film present since 1896. By 1936 it had already run the second National Festival of Egyptian Cinema where the first animated films, produced by the Belarusian Frenkel brothers, were screened. The brothers Herschel, Salomon, and David had emigrated from Palestine to Egypt following World War 1 and were carpenters by trade. The Frenkel brothers were pioneers in their own right, as they reinvented the mechanisms and processes required to make an animation; from drawings to making cameras, recording and developing of the film, and constructing their own assembly board. ${ }^{42}$ They were described as cinephiles who loved Walt Disney (screened in Egypt for the first time in 1930) and who re-invented Mickey Mouse with their own version Marco Monkey ${ }^{43}$. Marco Monkey was the first animated film made by the brothers in 1935 but was not considered as successful as their later work. The film was criticized in local news for the rudimentary nature of the animation, an event that is said to have spurred the brothers on to perfect their technique and make Mish Mish Effendi. ${ }^{44}$ In contrast, the animated series Mish-Mish Effendi was much more popular and local news reported favorably on the charm of this series. The main character Mish Mish had a strong aesthetic resemblance to early 
Disney cartoons and was considered somewhat of a 'national hero'. However it is the Arab Egyptian Antoine Selim Ibrahim with his films Aziza and Youness (1938), and Dokdok (1940) who is considered to be the first Egyptian animator, as opposed to the Frenkel brothers who were seen as immigrants. ${ }^{45}$

The Egyptian revolution of 1952 that replaced the monarchy with a republic had a significant impact upon the production of animation in Egypt. The nationalistic agenda prompted a flourish in the production of didactic content although heavily censored, and animators like the Frenkel brothers left Egypt to continue their work in France. By the 1960s, cinema was on the decline and television was the dominant platform for animation, which by this time had mostly found it place in advertising. A notable figure during this time was the animator Ali Muhib ${ }^{46}$ - who also collaborated with his brother Husam. ${ }^{47}$ These two artists experimented with different processes including rotoscoping and were able to achieve animations that were on a par with those made by studios. This work led to the professional appointment of these artists as heads of the Animation Department for National Television in 1960. The department consisted of a small group of young graduates from the Academy of Fine Arts, including Mohammed Hassib, Noshi Iskandar, Redha Goubran, Ahmed Saad, Abdellaim Zaki, Hassan Anbar, Abdel Anwar, Raouf Abd El-Hammed, Fahmy Abd El-Hammed, Fayza Hussein and Shweikar Khalifa. ${ }^{48}$ The animations that were produced between the 1950s until the 1970s, unlike those of the Frenkel brothers, were influenced by the aesthetic of the Zaghreb School of animation and not by the American styles. By 1979, Ali Muhib had directed his first animated television series, Mishgias Sawah, intended for a Saudi audience. 
Mohamed Ghazala, an Egyptian animator and professor in animation studies from Minia, identifies the period from 1990 onwards as the 'golden era of Egyptian animation'. ${ }^{49}$ During this time, animation thrived notwithstanding a lessening of official government support. Egyptian animation grew to accommodate a range of animation festivals, animation associations, guilds, and a chapter of ASIFA (International Animated Film Association). In 2011, the Arab spring, also galvanized Egyptian artists who were used to working in a climate of self-censorship. Like other artists on the continent they took advantage of the freedoms afforded by digital technologies including affordable mobile technologies and Internet connections. Social media became a powerful platform to disseminate work, and the previous formats of production, dissemination and consumption of animation were transformed. This resulted in young artists working independently online and experimenting freely with digital technology.

Similar reports of a renaissance of artistic activity connected to political and technological milieus (whether through the introduction of television in 1960s, or the Internet) in Northern Africa can be found in the accounts of animation from Libya, Tunisia, Algeria and Morocco. ${ }^{50}$ In Algeria, Mohamed Aram began his work in the wake of post-colonial independence, producing animations for local television in the 1960s underpinned by a strong educational intention and a social function. Similarly, the first examples of Tunisian animation in the 1960s also took the form of educational content driven by nationalistic intentions. In its beginnings, the work of Tunisian autodidacts such as Mongi Sancho and Habib Masrouki shared the postindependence optimism that most filmmakers across the continent experienced. However the changing political climate of social and political crisis in the seventies 
and the eighties saw some other pioneers like Zouhair Mahjoub leaving to pursue their ambitions to make animation in Czechoslovakia and returning later after the 1987 coup d'état. From the 1990s onwards it was possible to find more subversive animation in the form of allegories, and later more direct and satirical critiques of local politics in animation.

In Libya, animators inspired by political cartoonists like Mohammed Zwawi, went on to make Boq at Jaw (2010), a humorous animated cartoon about two archetypal Libyan characters with different outlooks, who regularly bump into each other to have small topical conversations. The animated series was made before, during and after the revolution (2010-2013) and went viral on social media. It has been discussed as an example of 'political art as a medium of dissent'. ${ }^{51}$ To a degree, Boq at Jaw, resembles the Moroccan 3D computer animation Rass Derb (2010) by Rachid Jadir, literally translated as 'the corner of the street'. In this animation the characters chat about the everyday, in a sincere depiction of Moroccan youth tackling social issues, such as the exploitation of young Moroccan girls by foreign Arab men. Moroccan animation appears later than other examples from this region, with Hamid Semlali's Didi, la poule made in 1984. By the early 1990s, a group of art graduates set up a small studio CASAPremiere and worked on commercial projects for television. Like other narratives across the continent, with the appearance of digital technologies from 2000, Moroccan animation had gained momentum and a young generation of enthusiasts were creating material intended for online distribution and circulation, and which typically circumvented conventional institutional gatekeepers. This rise in activity in the region and its visibility may be in part connected to the political climate of the Arab spring in combination with the growth and access to digital technology, as 
a noted change in pace has been described by many scholars following these specific socio-political and technological contexts ${ }^{52}$.

\section{Social Realism and the Fantastical: The Political and Subversive}

Mirroring several of the tones and motivations of early post-colonial films, some cases of African animation present a negotiation of social realist concerns embedded within a fantastical or fabricated image. Typically the term 'realism' does not sit with ease alongside animation, and for sometime academic discussions in animation studies have been grappling with presenting a case for 'so-called' animated documentaries. Some of the examples discussed in this section straddle the real and unreal through the manipulation of aesthetic form and sound, and represent nonfiction or personal testimony within animation. These artists capitalise on the aesthetic range and scope that animation offers in order to be able to subvert institutional censorship and offer political critique or commentary.

In Kenya, the post-election violence between 2007 and 2008 was a pivotal moment in political history that resulted in a cohering of different moving image artists to offer creative commentaries on this experience across a range of formats. Inspired and spurred on by the political cartoonist, Godfrey Mwampembwa (Gado) and his political satire television program, The XYZ Show, other artists began making similar short animations. Mwampembwa more commonly known for his work in print cartooning, was also trained in animation. The XYZ Show consisted of puppets designed off Mwampembwa's caricatures and was based upon programs like British television show Spitting Image (1984-1996) or the French show Les Guingols (1988- 
). These shows conventionally use large caricatured latex puppets to parody local politicians and celebrities in a talk-show format that satirizes the news.

The Kenyan political animations that were made during this time circulated mostly through unofficial channels such as online streaming, home-made DVD sales in local markets, or even in the Goethe Institute gallery, as opposed to mainstream media. The XYZ Show on the other hand was aired on NationTV, a television station that is owned by the Nation Media Group also responsible for leading publications such as The Daily Nation, although this was not without difficulty ${ }^{53}$. The animations produced during this period, 2008 - 2012 included; The Stated Opinion Show (2007) by Musa Ihiga, a chat show format with political figures as 2D cartoons; The Greedy Lords of the Jungle (2009) by Gatumia Gatumia, an adaptation of a Gikuyu story in Jomo Kenyatta's book Facing Mount Kenya (1939) which was seen as a parody of British colonial government; Wageuzi Battle 2012, a 3D computer animation that was distributed online referencing the Transformers franchise where Kenyan politicians battle as transforming robots; the installations at the Goethe by Just a Band for their exhibition TRNSMSSN, including the pieces SomeHow (2009), and 2012, The Sequel (2009) collaborations with the photojournalist Boniface Mwanga; the Emmy-award winning Shujaaz (2010) transmedia project, designed to encourage political engagement in the youth. ${ }^{54}$ In an interesting turn of events, by 2012, some of the artists that had worked with Mwampembwa on The XYZ Show went on to make commissioned work for NGO's and government bodies. These organizations wanted to deploy animation and games as part of a campaign to encourage peaceful elections. They included the Wazi Campaign (2013), a series of 3D computer animated shorts and The Election Thief (2013), a platform game for mobile phones. These examples 
occurred around a specific political moment in Kenya, and it is possible to identify similar aesthetic strategies associated with animation such as caricature, humour, parody and metaphor across a range of animations in Libya and Tunisia, for example, and also connected to the political activism during the Arab Spring (2010-2012). ${ }^{55}$

There are also several auteurs that have explored social realism either through their fictional narratives, such as Kibushi's film Muana Mboka (1999) or through an engagement with documentary format such as Trowell's Beyond Freedom (2006), Kibushi's Septembre Noir (1992), Mukii's Yellow Fever (2012) and Arthur's Black Barbie (2016), and Untitled (2017). With Muana Mboka (1999), Kibushi offers a critique of Congolese institutions of power through the story of a young street boy. He also draws upon a painterly aesthetic that is firmly located in the traditions of Congolese popular painting, in a cut-out animation. ${ }^{56}$ The latter group of examples are all underpinned by 'testimonies' whether personal or belonging to others that frame and locate the animation as so-called documentary as opposed to fiction. These testimonies in combination / with the fabricated image (as opposed to the photographic), offer an interesting visual engagement with memory and truth. They invite the viewer to reflect upon why the artist has used drawings, paintings, photographs or collage to illustrate these accounts. With Septembre Noir (1992), Kibushi uses images drawn by children who witnessed the military coup in Kinshasa on the $23^{\text {rd }}$ Septembre 1991 . Here testimony takes the form of a child's drawing from memory, framed by Kibushi's poetic narrative in sound. In contrast, other animators use sound to drive the images. Beyond Freedom (2006) for example collects video interviews from different South Africans who discuss their experiences of apartheid and conceptions of freedom. Then the image is replaced by a series of drawn 
animated images made by different artists to illustrate the dialogue drawing upon techniques such as visual metaphor, anthropomorphic characters, metamorphic and fluid change of states. The sound can also present itself as a personal testimony, in the case of Yellow Fever (2012), for example as an oral account of a memory experienced by the artist, as they reflect upon skin colour and identity. ${ }^{57}$

\section{Festivals}

Festivals have historically played an important role in the visibility and dissemination of animated films. They have also played a part in gatekeeping through programming selections that can unwittingly play a part in the exclusion of different voices in world animation. That said, from 2008, there was a noted increase in the inclusion of African animations in various European International animation festivals; Fantoche International Animation Festival 2009, Switzerland; AnimFest 2009, Czech Republic; Africa in Motion Film Festival 2008/ 2009, Edinburgh; Animabasauri Animation Festival 2008, Spain. In addition there was some evidence of animation and film festivals in Africa promoting local content, such as: Animafrik, Ghana, the Kenya International Film Festival, Kenya, the Luxor Film Festival, Egypt, the Meknes Animation Festival, Morocco, Malagasy International Film Festival, Madagascar, Durban International Film Festival and Cape Town International Animation Festival, South Africa. In 2012, Annecy Animation Festival (the largest animation festival in Europe) presented a 'Focus on African Animation' with four animated films, two by Kader Ouattara and Lazare Sie Pale from Burkina Faso and two by Sitraka Randriamahaly and Ridha Andriatomanga from Madagascar. ${ }^{58}$ Then in 2014, Afrikamera, Berlin's African Film Festival hosted a collaboration between German 
animators and three Malagasy animators, Khafez Ranirison, Sitraka Randriamahaly and Manohiray Randriamananjo to produce an animated short in 48 hours. ${ }^{59}$

In 2017, one of the largest African animation festivals, FupiToons, was held in South Africa. It claimed it received 114 entries to the festival, suggesting the making of animation is not in short supply. That same year, Annecy Animation Festival partnered with the African Animation Network, and DISCOP to launch Animation without Borders as the first pan-African pitching competition where animators are given the opportunity to showcase proposals for a range of animations in development that are looking for producers, distributors or financiers. ${ }^{60}$ It is worth pointing out however that whilst animation and film festivals have been the conventional means to promote and obtain support for ones work, digital technology has impacted greatly upon the spaces of distribution and consumption of audio-visual material. This is important as it? can be seen to respond to the potential gatekeeping that can result in the festival circuit.

\section{Digital Spaces - Trajectories of Current Practices}

The landscape for African animation is rapidly changing in part aided and catalysed by the introduction and ease of access of digital technologies and the Internet. The digital traces that the African animators leave on the Internet for storage, distribution, and exhibition can include a range of things, such as their documents, drawings, photos, animations, videos, websites, blogs, comments in chat rooms, social pages, and so on. Animators such as Kenneth Coker (Nigeria), Mike Scott (South Africa), Kwame Nyongo (Kenya), Alfred Muchilwa (Kenya), Mike Muthiga (Kenya), Ebele 
Okoye (Nigeria), Adamu Waziri (Nigeria), Ezra Wube (Ethiopia), Serge Pitropia (Burkina Faso), Bruktawit Tikabu (Ethiopia) to name a few key figures, have multiple blogs and websites, online video streaming channels, alongside their social networking profiles, and capitalize upon these technologies to promote their work and foster collaboration.

In 2015, the MakingAfrica exhibition at the Vitra Design Museum, Germany, included diverse incidences of animation across a range of forms, in games developed for mobile platform, in Wangeci Mutu's surreal The Art of eating everything (2010), or as a technique deployed as CGI (computer generated imagery) in the Kenyan afrofuturist film Pumzi (2009) directed by Wanuri Kahiu, or as the hypnotic animated gifs by Francois Beaurain of Liberia. Games and related forms such as interactive narratives are increasingly intertwined with animation discourse as they are arguably incidences of animation within other forms. The exhibition included work from across the continent, whether the Nigerian Maliyo Games' application to squash mosquitos, or Kenyan Leti Arts Africa's Legends (2013) fighting game with African superheroes based on characters from various African mythologies. The discourse of animation in a digital context must engage with conceptions of animation that do not strictly adhere to the conventional 2D children's format, and that can appear as a practice in modes that may have a photographic aesthetic with CGI, or in an interactive space in computer games, or even as animated gifs. ${ }^{61}$ African animation is increasingly making strides in this field, with developments in computer games and artists that are straddling a range of visual practices whether filmmaking, animation, painting, photography, and even computer animation in all its guises. ${ }^{62}$ 
The economy in animation production methods that results from the use of tools (software or hardware) provided by computer and mobile phone technologies, enable a range of different production processes to sit within a single platform. This in turn, facilitates independence from wider institutional and infrastructural bodies. 'Start-up' animators in Africa are able to script, design, animate, record sound, and render their animation in a format ready for easy distribution, all using one or two devices.

Now African animation is able to circumvent traditional modes of dissemination, with new visibilities across a range of virtual spaces. These modes have allowed some artists degrees of subversion and freedoms, however the lack of material physicality inherent to the digital artefact means that its trace can be easily lost amongst the amassing online data.

\section{Conclusion}

Animation artists across Africa have made work that is informed by the cultures of the spaces they operate within and the specific social, economic and political histories of these places. In light of the varied landscapes that impact upon the narratives of animation from this continent, the all-encompassing term 'African animation' is a nomenclature that falls short of describing this diversity. In addition, African animation artists straddle a range of artistic practices and their work exists in diverse genres and formats. These include but are not limited to children's cartoon educational programs on television intended to depict local stories and safeguard languages; drawn caricatured political satire distributed via YouTube as a form of socio-political critique or activism; mixed-media documentary and non-fiction animation, as personal testimony or as a voice for the marginalized, screened at festivals, mobile cinemas, or at exhibitions in galleries; and finally with the onset of 
digital technologies computer animation as short viral 3D animations that are shared across social networking spaces or computer animation within games designed to be played on a mobile phone.

\section{Filmography}

9 Drawings for Projection (2005), [9 Animation Projections], by William Kentridge.

Amora (2009), [Animation], directed by E. Wube.

A Woman married three men (La Femme mariee a tres homes) (1992), [Animation], directed by C. Sawadogo, NFB Canada.

Beyond Freedom (2005), [Animation], directed by J. Trowell, Big World Cinema.

Bino \& Fino (2009 - ), [Series Animation], directed by A. Waziri, EVCL Productions.

Bon Voyage Sim (1966), [Animation], directed by M. Alassane.

Downrising (2006), [Animation], directed by B. Kilonzo, UNESCO Africa Animated DVD Collection.

Iwa (2009), [Animation], directed by K. Coker.

Kabongo, Le Griot (2000), [TV Series Animation], directed by P. Sauvalle

Kinshasa Septembre Noir (1992), [Animation], directed by J.M. Kibushi, Studio Malembe Maa.

Kokoa (1985), [Animation] directed by M. Alassane, POM Films.

Les Palabres de Mboloko (1951 -1956), [Series Animation], directed by R. Jamar, Commissioned by A. Vandenheuvel.

Le Mort de Gandji (1965), [Animation], directed by M. Alassane.

Prince Loseno (2004), [Animation], directed by J.M. Kibushi, Studio Malembe Maa.

Samba le Grande (1977), [Animation], directed by M. Alassane.

Souvenir du vide, 2011-2015, [42 Animation Projections], by Massinissa Selmani, Venice Biennale, 2015. 
Takalani Sesame (2000), [TV Series Animation], TriggerFish Studios.

The Artists Dream (1916), [Animation], directed by H. Shaw, Killarney Film Studios.

The End of Eating Everything (2013), [Animated Video] by Wangeci Mutu.

The Greedy Lords of the Jungle (2009), [Animation] directed by Gatumia Gatumia.

The XYZ Show (2009-), [TV Series], directed by G. Mwampembwa, BuniTV.

Toto's Journey (2005), [Animation], directed by A. Muchilwa, G. Semwaiko, UNESCO Africa Animated.

Tree of Spirits (2005), [Animation], directed by C. Sawadogo, Planete Films, CineFete.

Wageuzi: Battle 2012 (2011), [Animation], directed by A. Kaggia

Yellow Fever (2012), [Animation, Documentary], directed by N. Mukii.

Zambezia (2009), [Animation], directed by W. Thornley, Trigger Fish Studios, CMG, DTI, NFVF, Wonderful Works, 120dB Films.

\section{Further Reading}

Armes, Roy. African Filmmaking: North and South of the Sahara, (Edinburgh, 2006).

Barlet, Olivier. African Cinemas: Decolonizing the Gaze. (London, 2000).

Bazzoli, Maria Silvia. African CartoonIl Cinema di animazione in Africa, (Milano, 2003). 
Bendazzi, Gianalberto. 'African Cinema Animation', Enter Text: an interdisciplinary humanities e-Journal, 4,1 (2004), 10-26.

Benimana, Benjamin, 'L'esthetique du Cinema D'Animation Africain', in J. Kibushi, and L. Emongo (ed.), Hommage au cinéma d'animation d'Afrique noire, (Strasbourg, 2001), 12-19.

Bickford-Smith, Vivian and Richard Mendelsohn. Black and White in Colour: African History on Screen, (Oxford, 2007).

Botha, Martin, South African Cinema 1896-2010. (Bristol, 2012).

Callus, Paula. 'Animation as a socio-political commentary: an analysis of the animated films of Congolese director Jean Michel Kibushi' in Journal of African Media Studies, 2, 1 (2010), 55-71.'

Callus, Paula. 'Animation, fabrication, photography: Reflections upon the intersecting practices of sub- Saharan artists within the moving image'. African Arts, 48, 3 (2015), 58-69.

Convents, Guido. 'Da artigiano a professionista. La lunga e difficile strada di una passione', in M.S. Bazzoli (ed.), African Cartoon, (Milano, 2003), 67-71.

Convents, Guido. Images and Animation: Le Cinema d'animation en Afrique Centrale (Leuven, 2014). 
Diawara, Manthia. African Cinema. (Indianapolis, 1992).

Edera, Bruno. 'African Animation', in J. Greene and D. Reber (ed.), Drawing Insight: Communicating Development through Animation, (Malaysia, 1996), 111.

Edera, Bruno. A La Decouverte d'un Cinema Meconnu; Le Cinema D'Animation Africain, (Annecy, 1993).

Furniss, Maureen. Art in Motion: Animation Aesthetics, (Hêrts, 1998).

Gehman, Chris, Reinke, Steve. The Sharpest Point: animation at the end of cinema. (Ottowa, 2005).

Bendazzi, Giannalberto. Animation: A World History (Florida, 2015).

Givanni, June, ed. Symbolic Narratives/African Cinema: Audiences, Theory and the Moving Image. (London, 2000).

Gugler, Josef. African Film: Re-imagining a Continent, (Oxford, 2003).

Harrow, Kenneth (ed.). African Cinema: Post-Colonial and Feminist Readings. (Trenton, 1999). 
Kaye, Emma. 'The history of animation in South Africa', in M.S. Bazzoli (ed.), African Cartoon, (Milano, 2003), 43-48.

Pilling, Jayne. A Reader in Animation Studies, (London, 1997).

Pfaff, Françoise. Focus on African Films. (Bloomington, 2004).

Thackway, Melissa. Africa Shoots Back: Alternative Perspectives in Sub-Saharan Francophone African Film. (Oxford, 2003).

Ukadike, Nwachukwu Frank. Questioning African Cinema: Conversations with Filmmakers, (Minneapolis, 2002).

Van de Peer, Stefanie. Animation in the Middle East: Practice and Aesthetics from Baghdad to Casablanca. (London, 2017).

\section{Notes}

'A. Klein, 'AfroAnime Series Looks To Tap Into The Emerging Market Of African Magical Futurism' in OkayAfrica, 24/08/2105. http://www.okayafrica.com/red-origins-african-magical-realism-animatedseries/, Accessed 10/01/2018.

`A. Bruns, Towards Produsage: Futures for User-Led Content Production’ in F. Sudweeks, H. Hrachovec, and C. Ess, (eds.), Proceedings Cultural Attitudes towards Communication and Technology 2006, (Estonia, 2006), 275-284.

${ }^{3}$ M. Furniss, Animation: The Global History, (New York, 2017). S. Reinke, C. Gehman (eds.), The Sharpest Point: animation at the end of cinema, (Toronto, 2005).

“ B. Edera, A La Decouverte d'un Cinema Meconnu; Le Cinema D'Animation Africain, (Annecy, 1993), 55 .

'L. Felperin, 'The thief of Buena Vista: Disney's Aladdin and Orientalism in J. Pilling (ed.), A Reader in Animation Studies, (London, 1997), 137-142.

'W. Mortiz, 'Narrative Strategies for resistance and protest in Eastern European animation' in in J. Pilling (ed.), A Reader in Animation Studies, (London, 1997), 38-47, W. Mortiz, 'Resistance and subversion in the animated films of the Nazi era' in in J. Pilling (ed.), A Reader in Animation Studies, (London, 1997), 228-240.

L. Manovich, The Language of New Media, (Cambridge, 2001). 
'H. Jenkins, Convergence Culture: Where Old and New Media Collide, (New York, 2006).

- O. Barlet, African Cinemas: Decolonizing the Gaze, (London, 2000). M. Diawara, African Cinema, (Indianapolis, 1992). K. Harrow, ed., African Cinema: Post-Colonial and Feminist Readings, (Trenton/Asmara, 1999). R. Armes, African Filmmaking: North and South of the Sahara, (Edinburgh, 2006).

10 This work is more readily referred to as a moving image piece or video art rather than 'animation' per se, in addition some of these artists are known more for other pieces in their work including painting, installations, collage.

"B. Edera, 'African Animation', in J. Greene and D. Reber (ed.), Drawing Insight: Communicating Development through Animation, (Malaysia, 1996), 111.

B. Edera, A La Decouverte, 6.

${ }^{13}$ N. Mirzoeff, 'The Multiple View Point' in N. Mirzoeff (ed.), A Visual Culture Reader; Second Edition, (London, 1998), 208.

${ }^{\prime}$ R. Al Shafi' a, 'Il Cinema di Animazione in Egitto' in M. Bazzoli (ed.), African Cartoon: Il Cinema d' Animazione in Africa, (Milano, 2003), 25-32. E. Kaye, 'Storia del Cinema di Animazion in Sudafrica' in M. Bazzoli (ed.), African Cartoon: Il Cinema d' Animazione in Africa, (Milano, 2003), 43-47. T. Chikhaoui, 'Il cinema di animazione in Tunisia. Indizi per una storia a venire' in M. Bazzoli (ed.), African Cartoon: Il Cinema d' Animazione in Africa, (Milano, 2003), 37-42. D. Frenkel, 'I fratelli Frenkel artigiani in Egitto' in M. Bazzoli (ed.), African Cartoon: Il Cinema d' Animazione in Africa, (Milano, 2003), 33-36. G. Gariazzo, 'Il gesto che cancella e riproduce ovvero i film-pittura di William Kentridge', in M. Bazzoli (ed.), African Cartoon: Il Cinema d' Animazione in Africa, (Milano, 2003), $49-52$.

is S. Van de Peer, Animation in the Middle East: Practice and Aesthetics from Baghdad to Casablanca, (London, 2017), 24.

${ }^{16}$ M. Ghazala, 'From the Pioneers to the Revolutionaries: The Art of Animation in Egypt', in S. Van de Peer (ed.), Animation in the Middle East: Practice and Aesthetics from Baghdad to Casablanca, (London, 2017), 196-216.

"N. Mansour, 'Animating Libya in Shorthand: The Skilful Art of Visualising the Repressed Body', in S. Van de Peer (ed.), Animation in the Middle East: Practice and Aesthetics from Baghdad to Casablanca, (London, 2017), 217-239.

${ }^{\circledR}$ M. Ben Ayed, 'Cinema Against an Authoritarian Backdrop: A History of Tunisian Animation', in S. Van de Peer (ed.), Animation in the Middle East: Practice and Aesthetics from Baghdad to Casablanca, (London, 2017), 240-261.

${ }^{19}$ P. Callus, 'Animation in Morocco: New Generations and Emerging Communities', in S. Van de Peer (ed.), Animation in the Middle East: Practice and Aesthetics from Baghdad to Casablanca, (London, 2017), 262-281.

º J. A. Wright, Animation Writing and Development, (Oxford, 2005), 34.

"J. A. Wright, Animation Writing and Development, (Oxford, 2005).

${ }^{22}$ S. Shapurjee, 'A Historical Enquiry into the Animation Unit, situated within the South African Broadcasting Corporation (SABC) 1976-1988,' (Masters diss., University of the Witwatersrand, Johannesburg, 2008).

${ }^{23}$ M. Botha, South African Cinema 1896-2010. (Bristol, 2012), 52.

${ }^{24}$ It should be noted, that this advanced industrialization derived from its colonial and apartheid trajectory integrated it more closely into the Western industrialized complexes since the late 19th Century.

${ }^{25}$ G. Bendazzi, Animation: A World History: Volume III Contemporary Times, (New York, 2016), 307. L. Godfrey, 'Triggerfish Aims for Takalani Sesame', in AWN.com (Animation World Network), 16/10/2002. https://www .awn.com/news/triggerfish-aims-takalani-sesame Accessed 13/10/2017.

${ }^{26}$ B. Hosea, 'Drawing Animation' in Animation: an interdisciplinary journal, 5,3 (2010), 353-367. R. Krauss, 'The Rock: William Kentridge's Drawings for Projection' in S. Reinke, C. Gehman (eds.), The 
Sharpest Point: animation at the end of cinema, (Toronto, 2005) 96-126. D.H. Fleming, 'Charcoal Matter with Memory: Images of Movement, Time and Duration in the animated films of William Kentridge' in Film-Philosophy Journal, 17,1 (2013), 402-423. M. Godby, 'William Kentridge: Retrospective' in Art Journal, 58,3 (1999), 74-85. J. Dubow, R. Rosengarten, 'History as the main complaint: William Kentridge and the making of post-apartheid South Africa' in Art History, 24,4 (2004), 671-690. M. Rosenthal, William Kentridge: Five Themes (San Francisco Museum of Modern Art), (New Haven, 2009).

${ }^{2}$ P. Callus, 'Animation as a socio-political commentary: an analysis of the animated films of Congolese director Jean Michel Kibushi’ in Journal of African Media Studies, 2,1 (2010), 55-71.

${ }^{28}$ O. Barlet, African Cinemas: Decolonizing the Gaze,(London, 2000). M. Bazzoli (ed.), African Cartoon: Il Cinema d' Animazione in Africa, (Milano, 2003).

${ }^{2}$ K. Harrow, African Cinema, 286. F. N. Ukadike, Questioning African Cinema: Conversations with Filmmakers. (London, 2002), 77.

${ }^{30}$ V. Cayla, 'Mustapha Alassane is made Knight of the Legion of Honour Speech by Véronique Cayla and Mustapha Alassane's reply', in Africultures, Association Africultures: Nyon 16/ 07/2007. http://www.africultures.com/php/index.php?nav=article\&no=6682 Accessed 28/07/2010.

B. Edera, A La Decouverte, 24

"D. Ababio, 'Animation: A Teacher's Perspective - A report of the International Symposium, Urbino, Italy', in D. Ross (ed.), CILECT (Centre International de Liaison des Ecoles des Cinema et de Television), September (1992), 37-39.

B. Edera, A La Decouverte, 24

${ }^{34}$ Personal Communication, S. Quartey, 11/06/2010

"B. Edera, A La Decouverte, 24

See: http://www.animafrik.com Accessed 20/1 1/2017

${ }^{3}$ D. Paez, 'Meet the passionate artists who are building an animation industry in Ghana' in CartoonBrew Online, 12/22/2016. http://Www .cartoonbrew .com/business/meet-passionate-artistsbuilding-animation-industry-ghana-146847.html Accessed 10/11/2017.

${ }^{38}$ O. Medubi, 'Nigerian Animation: Large Canvas, Little Movement' in J.A. Lent (ed.), Cartooning in Africa, (New York, 2009), 197-215.

Personal Communications, K. Nyongo, D. Muli, A. Mwaniki, A. Muchilwa, 2004 - 2009.

« Most of the artist's work can be viewed online on his personal website at ezrawube.net

"P. Callus, 'Animation, fabrication, photography: Reflections upon the intersecting practices of subSaharan artists within the moving image' in African Arts, 48,3 (2015), 58-69.

"D. Frenkel, 'I fratelli Frenkel, artigiani in Egitto', in M. Bazzoli (ed.), African Cartoon: Il Cinema d'Animazione in Africa, (Milano, 2003), 34.

${ }^{*}$ M. Ghazala, 'From the Pioneers', 199.

"R. Al Shafi'a, 'Il Cinema di Animazione in Egitto', in M. Bazzoli (ed.), African Cartoon: Il Cinema d'Animazione in Africa, (Milano, 2003), 25.

${ }^{4}$ M. Ghazala, 'From the Pioneers to the Revolutionaries: The Art of Animation in Egypt', in S. Van de Peer (ed.), Animation in the Middle East: Practice and Aesthetics from Baghdad to Casablanca, (London, 2017), 200.

${ }^{4}$ Ali Muhib is also referred to in some literature as Ali Moheeb.

${ }^{"}$ Husam is also referred to in some literature as Hossam El-Deen.

«s M. Ghazala, 'From the Pioneers', 203. R. Al Shafi'a, 'Il Cinema di Animazione in Egitto', 26.

‘9 M. Ghazala, 'From the Pioneers', 208. 
${ }^{\text {so }}$ T. Chikhaoui, 'Il Cinema di animazione in Tunisia. Indizi per una storia a venire' in M. Bazzoli (ed.), African Cartoon: Il Cinema d'Animazione in Africa, (Milano, 2003), 37- 42. M. Ben Ayed, 'Cinema Against an Authoritarian Backdrop', 240-261. N. Mansour, 'Animating Libya in Shorthand', 217-239.

P. Callus, 'Animation in Morocco', 262-281.

${ }^{\text {si }}$ N. Mansour, 'Animating Libya in Shorthand', 218.

${ }_{22}$ S. Van de Peer, Animation in the Middle East, 24. P. Callus, 'Animation in Morocco', 276. N. Mansour, 'Animating Libya in Shorthand', 218.

s P. Callus, 'The Rise of Kenyan Political Animation: Tactics of Subversion' in: P. Limb and O. Tejumola, (eds.), Taking African Cartoons Seriously: Satire, Politics and Culture, (East Lansing, Michigan, 2018).

${ }^{54}$ Shujaaz meaning 'heroes' in Kenyan slang Sheng

"N. Mansour, 'Animating Libya in Shorthand', 217-239. M.B. Ayed, 'Cinema Against an Authoritarian Backdrop', 240-261. S. Van de Peer (ed.), Animation in the Middle East, 1-28.

${ }^{56} \mathrm{P}$. Callus, 'Animation as a socio-political commentary', 59.

"P. Callus, 'Animation, fabrication and photography', 62.

${ }_{s s}$ This program can be found at https://www.annecy.org/about/archives/2012/2012-creativefocus/focus-on-african-animation-2012 Accessed 03/11/2017.

ss See http://africultures.com/afrikamera-2014-de-la-production-aux-festivals-de-cinema-12550/ Accessed 03/11/2017.

${ }^{60}$ http://www.animationmagazine.net/events/annecy-animation-du-monde-program-allies-with-africa/

${ }^{6}$ L. Manovich, 'What is Digital Cinema?' in Telepolis, (Munich: 1996).

${ }^{62}$ P. Callus, C. Potter, 'Video Michezo: Nairobi's gamers and the developers that are promoting local content', in Critical African Studies, 9, 3 (2017), 302-326. 